\title{
Nursing students' awareness on hand hygiene
}

\author{
Tulin Yildiz, Ebru Onler, Gönül Akcay \\ Department of Surgical Diseases, Nursing, Tekirdag Namik Kemal University, Institute of Health Sciences, Tekirdag, Turkey
}

Received: 2020-07-14.

Accepted: 2020-08-12

This work is licensed under a Creative Commons Attribution 4.0 International License

J Clin Med Kaz 2020; 6(60):44-47

Corresponding author:

Tulin Yildiz. E-mail: tyildiz70@hotmail.com; ORCID: 0000-0002-4981-6671

\section{Abstract}

Objective: The study has been implemented to identify hand hygiene awareness of potential healthcare professionals who study at Nursing Department affiliated to two public universities.

Material and methods: This was a descriptive research study, the research was in the nursing students (2, 3, 4 class) of two state universities between February and March 2017. Department of two selected public universities whereas the sampling covered 902 students, currently present at school, during the time of research as well as having approved to take part in the study. The data was analysed via computerbased methods including frequency (percentage) analysis, t test, MannWhitney $U$ and Chi-Square tests. The scores were accepted significant within 95\% reliability scale at $p<0.05$ significance level.

Results: 775 students responded positively (85.9\%) to the statement saying "healthcare professionals' hands become a risk factor for microorganism transfer to patients" compared to 127 participants who responded negatively (14.1\%). The statement proposing "your insufficient hand hygiene practices become a reason for crosscontamination of hospital infections" was responded positively (87.3\%) by 787 participants whereas negatively $(12.7 \%)$ by 115 students. The presumption on microorganisms' transfer to patients usually done by healthcare professionals' hands was responded positively by sophomore students at $79.3 \%$ has been found statistically and significantly lower than the juniors' positive response rate (88.5\%) and seniors' similar responses (89.7\%) (X2=15.960; $p=0.000)$.

Conclusion: The results display that awareness of nursing students on hand hygiene has gender-based and class-based variations. It is assumed that keeping up hand hygiene trainings at each year will possibly increase the awareness of nursing students.

Key words: hand hygiene, nursing students, hospital infections
Poor hand hygiene $(\mathrm{HH})$ lies at the root of nosocomial infections, and is an essential part of the nursing school curriculum [1]. Healthcare-associated infections (HAIs) are the most common complications that affect hospitalized patients [2,3]. In the whole world, it is of significant public health importance, as it poses a threat to the safety of patients $[2,4]$. Hand hygiene $(\mathrm{HH})$, a simple and low-cost measure, remains the leading intervention for reducing the burden related to healthcare-associated infections (HAIs). Preventing HAIs and their associated risk to safety requires the correct application of infection prevention and control (IPC) precautions, particularly hand hygiene practices $[5,6,7]$. Hand hygiene is an important aspect of controlling the spread of HAI [8]. Hand hygiene can reduce the spread of pathogenic microorganisms to patients and healthcare workers [9]. Since 2010, infection-control liaison nurses have been trained to conduct monthly cross-ward audits using the WHO hand hygiene tool to measure hand hygiene compliance rates [9]. This study was planned to determine the hand hygiene awareness of nursing students at two state universities that will be among the health professionals of the future.

\section{Material and methods}

This was a descriptive research study, the research was in the nursing students (2, 3, 4 class) of two state universities between February and March 2017. Approval was granted by the institutional ethics committee and informed consent for participation in the study was obtained for all the nursing students. The students in the class, the sample in the days when the study was done, and consisted of 902 students who had accepted the research. Data were gathered form the demographic data form and survey with hand hygiene awareness which was developed by the researchers, applied through face to face interviews with the patients. Survey questionnaires consisting of twenty questions in total, were given to students in order to 
understand their awareness of about hand hygiene. The internal consistency was measured using Cronbach's Alpha test. The Cronbach's Alpha coefficients of the responses which turned out to be 0.672 .

\section{Ethical considerations}

Written permission from university and informed consent from each of the participants were obtained for the research. The study was approved by the Ethical Committee of a University Medical Faculty Non-Interventional Clinical Research, No: 2017/31/01/02.

\section{Data analysis}

Descriptive statistic was used to present the results of the survey. While evaluating the findings of the study, all analyses were conducted by institutional statistics program. Unpaired
Summary of studies: outcomes, measures, and results

\begin{tabular}{|l|l|l|l|}
\hline \multicolumn{2}{|l|}{ Variables } & $(\mathrm{n})$ & $(\%)$ \\
\hline \multirow{3}{*}{ University } & State 1 University & 555 & 61,5 \\
\cline { 2 - 4 } & State 2 University & 347 & 38,5 \\
\hline \multirow{3}{*}{ Age } & $18-25$ & 891 & 98,7 \\
\cline { 2 - 4 } & $26-30+$ & 11 & 1.21 \\
\hline \multirow{3}{*}{ Year } & 2 & 295 & 32,7 \\
\cline { 2 - 4 } & 3 & 305 & 33,8 \\
\hline \multirow{3}{*}{ Gender } & 4 & 302 & 33,5 \\
\hline \multirow{2}{*}{ Healthcare staff in the family } & Male & 206 & 22,8 \\
\cline { 2 - 4 } & Female & 696 & 77,2 \\
\hline & Yes & 226 & 25,1 \\
\cline { 2 - 4 } & No & 676 & 74,9 \\
\hline & Total & 902 & 100,0 \\
\hline
\end{tabular}

Relationship between hand hygiene knowledge and year of the nursing program.

\begin{tabular}{|c|c|c|c|c|c|c|c|c|c|}
\hline & \multicolumn{2}{|l|}{ Year 2} & \multicolumn{2}{|l|}{ Year 3} & \multicolumn{2}{|l|}{ Year 4} & \multirow{3}{*}{$\begin{array}{l}\mathrm{X}^{2} \\
4.612\end{array}$} & \multirow{3}{*}{$\begin{array}{l}P \\
0.100\end{array}$} \\
\hline & & \multirow{2}{*}{\begin{tabular}{|l|} 
Yes n(\%) \\
$258(87.5)$
\end{tabular}} & \multirow{2}{*}{$\begin{array}{l}\text { No } n(\%) \\
37(12.5)\end{array}$} & \multirow{2}{*}{$\begin{array}{l}\text { Yes n(\%) } \\
257(84.3)\end{array}$} & \multirow{2}{*}{$\begin{array}{l}\text { No n(\%) } \\
48(15.7)\end{array}$} & \multirow{2}{*}{$\frac{\text { Yes n(\%) }}{272(90.1)}$} & \multirow{2}{*}{$\begin{array}{l}\text { No } n(\%) \\
30(9.9)\end{array}$} & & \\
\hline 1. & $\begin{array}{l}\text { Insufficient hand hygiene practices become } \\
\text { a reason for cross-contamination among } \\
\text { hospital infections. }\end{array}$ & & & & & & & & \\
\hline 2. & $\begin{array}{l}\text { I make great effort to practice good hand } \\
\text { hygiene. }\end{array}$ & $65(22.0)$ & $230(78)$ & $67(22.0)$ & $238(78)$ & $61(20.2)$ & $241(79.8)$ & 0.388 & 0.824 \\
\hline 3. & $\begin{array}{l}\text { For hand hygiene. it is necessary to take } \\
\text { alcohol-based solutions regularly. }\end{array}$ & $221(74.9)$ & $74(25.1)$ & $202(66.2)$ & $103(33.8)$ & $206(68.2)$ & $96(31.8)$ & 5.859 & 0.053 \\
\hline 4. & $\begin{array}{l}\text { Using gloves replaces hand hygiene } \\
\text { requirement. }\end{array}$ & $18(6.1)$ & $277(93.9)$ & $45(14.8)$ & $260(85.2)$ & $21(7)$ & $281(93.0)$ & 16.285 & 0.000 \\
\hline 5. & $\begin{array}{l}\text { Healthcare professionals' hands become a risk } \\
\text { factor for microorganism transfer to patients. }\end{array}$ & $234(79.3)$ & $61(20.7)$ & $270(88.5)$ & $35(11.5)$ & 271(89.7) & $31(10.3)$ & 15.960 & 0.000 \\
\hline 6. & $\begin{array}{l}\text { Hand hygiene trainings adjust hand hygiene } \\
\text { malpractices }\end{array}$ & $283(95.9)$ & $12(4.1)$ & $288(94.4)$ & $17(5.6)$ & $287(95)$ & $15(5)$ & 0.741 & 0.690 \\
\hline 7. & $\begin{array}{l}\text { Patients still need to re-perform hand hygiene } \\
\text { although their hands are not contaminated. }\end{array}$ & $275(93.2)$ & $20(6.8)$ & $290(95.1)$ & $15(4.9)$ & $287(95)$ & $15(5)$ & 1.281 & 0.527 \\
\hline 8. & $\begin{array}{l}\text { Hand hygiene is not reduced if gloves do not } \\
\text { get dirty. }\end{array}$ & $240(81.4)$ & $55(18.6)$ & $224(73.4)$ & $81(26.6)$ & $224(74.2)$ & $78(25.8)$ & 6.298 & 0.043 \\
\hline 9. & $\begin{array}{l}\text { The improvement of hand hygiene compliance } \\
\text { reduces hospital-based infection speed. }\end{array}$ & 281(95.3) & $14(4.7)$ & 278(91.1) & $27(8.9)$ & $287(95)$ & $15(5)$ & 5.545 & 0.063 \\
\hline 10. & $\begin{array}{l}\text { Good hand hygiene is important for preventing } \\
\text { hospital infections. }\end{array}$ & $290(98.3)$ & $5(1.7)$ & $294(96.4)$ & 11(3.6) & $294(97.4)$ & $8(2.6)$ & 2.116 & 0.347 \\
\hline 11. & $\begin{array}{l}\text { It is necessary to practice hand hygiene before } \\
\text { going into the patient's room. }\end{array}$ & $290(98.3)$ & $5(1.7)$ & $297(97.4)$ & $8(2.6)$ & $294(97.4)$ & $8(2.6)$ & 0.773 & 0.679 \\
\hline 12. & $\begin{array}{l}\text { It is necessary to practice hand hygiene after } \\
\text { taking off the gloves. }\end{array}$ & $287(97.3)$ & $8(2.7)$ & $276(90.5)$ & $29(9.5)$ & $283(93.7)$ & $19(6.3)$ & 11.901 & 0.003 \\
\hline 13. & $\begin{array}{l}\text { It is necessary to practice hand hygiene before } \\
\text { preparing medication (treatment). }\end{array}$ & $284(96.3)$ & $11(3.7)$ & 285(93.4) & $20(6.6)$ & 293(97) & $9(3)$ & 5.097 & 0.078 \\
\hline 14. & $\begin{array}{l}\text { Poor hand hygiene results in cross- } \\
\text { contamination. }\end{array}$ & 289(98) & $6(2)$ & $284(93.1)$ & $21(6.9)$ & $289(95.7)$ & $13(4.3)$ & 8.346 & 0.015 \\
\hline 15. & $\begin{array}{l}\text { It is necessary to practice hand hygiene before } \\
\text { and after each intervention at the hospital. }\end{array}$ & $290(98.3)$ & $5(1.7)$ & 295(96.7) & $10(3.3)$ & $295(97.7)$ & $7(2.3)$ & 1.609 & 0.447 \\
\hline 16. & $\begin{array}{l}\text { We need to clean our hands before } \\
\text { touching the patient in order to prevent the } \\
\text { contamination of microorganisms. }\end{array}$ & 292(99) & $3(1)$ & 295(96.7) & $10(3.3)$ & 296(98) & $6(2)$ & 3.752 & 0.153 \\
\hline 17. & $\begin{array}{l}\text { It it necessary to practice hand hygiene just } \\
\text { after touching the patient and leaving his / her } \\
\text { room. }\end{array}$ & 291(98.6) & $4(1.4)$ & 291(95.4) & $14(4.6)$ & 298(98.7) & $4(1.3)$ & 8.962 & 0.011 \\
\hline 18. & $\begin{array}{l}\text { Prior to intervention and touch. it is necessary } \\
\text { to implement aseptic techniques so as not to } \\
\text { transfer microorganisms to other surfaces. }\end{array}$ & 286(96.9) & $9(3.1)$ & 293(96.1) & $12(3.9)$ & 293(97) & $9(3)$ & 0.533 & 0.766 \\
\hline 19. & $\begin{array}{l}\text { In order to prevent yourself and others } \\
\text { around. it is necessary to practice hand } \\
\text { hygiene after getting exposed to patient's body } \\
\text { fluids such as blood. serum and excretion }\end{array}$ & 292(99) & $3(1)$ & 296(97) & $9(3)$ & $298(98.7)$ & $4(1.3)$ & 3.745 & 0.154 \\
\hline 20. & $\begin{array}{l}\text { For your safety. it is necessary to practice } \\
\text { hand hygiene after touching the furniture and } \\
\text { objects around the patient though there is no } \\
\text { contact with him / her. }\end{array}$ & $288(97.6)$ & $7(2.4)$ & 296(97) & $9(3)$ & 293(97) & $9(3)$ & 0.259 & 0.878 \\
\hline
\end{tabular}


t-test was used to compare awareness of hand hygiene in the two groups and the Mann-Whitney $U$ test for those who did not show normal distribution. Chi-square test was performed for data analysis. Significance was evaluated at the level of $\mathrm{p}<0.05$.

\section{Results}

A total of 902 students completed the survey. The majority of participants were female (77.2\%), aged 18-25years (98.7\%). A slightly large percentage of participants were in year 3 and 4 of the nursing program (33.8\% and 33.5\% respectively) compared to year $2(32.7 \%)$. The majority of participants haven't healthcare professionals in the family (74.9\%) (Table 1).

Participants were asked 20 correctly/incorrectly questions to assess their knowledge of $\mathrm{HH}$. Chi-square (x2) statistics were performed to identify any differences in students' frequency of answering yes and no, by year level. The results for all 20 items are displayed in Table 2. For items 4, 5, 8, 12, 14 and 17 , a significant relationship was found between year level and students' responding yes/no. Year 2 and 4 year students were significantly more likely than expected to answer 4 items. Year 3 and 4 year students were significantly more likely than expected to answer 5 items.

Participants were asked 20 yes/no questions to assess their knowledge of HH. Chi-square (x2) statistics were performed to identify any differences in students' frequency of answering yes and no, by gender. The results for all 20 items are displayed in Table 3. For items 5, 10, 13, 14, 15, 16, 17 and 20, a significant relationship was found between gender and students' responding yes/no.

\section{Discussion}

Hands are the most common vehicle for the transmission of pathogens within the health care environment. Hand hygiene is the leading measure for reducing healthcare-associated infections (HCAIs) and preventing the spread of antimicrobial resistance $[9,10]$. As a member of the healthcare team, nursing students have direct patient contact during clinical practice; hence, good hand hygiene practice among nursing students is essential [11]. The study has been implemented on multi-settings to identify hand hygiene awareness of potential healthcare professionals who study at Nursing Departments affiliated to two public universities.

\begin{tabular}{|c|c|c|c|c|c|c|}
\hline & \multicolumn{2}{|l|}{ Male } & \multicolumn{2}{|l|}{ Female } & \multirow[t]{2}{*}{$\mathrm{X}^{2}$} & \multirow[t]{2}{*}{$\mathrm{p}$} \\
\hline & Yes n(\%) & No $n(\%)$ & Yes n $(\%)$ & No $n(\%)$ & & \\
\hline $\begin{array}{l}\text { Insufficient hand hygiene practices become a reason for cross- } \\
\text { contamination among hospital infections. }\end{array}$ & $177(85.9)$ & $29(14.1)$ & $610(87.6)$ & $86(12.4)$ & 0.423 & 0.515 \\
\hline I make great effort to practice good hand hygiene. & $49(23.8)$ & $157(76.2)$ & $144(20.7)$ & $552(79.3)$ & 0.9006 & 0.341 \\
\hline $\begin{array}{l}\text { For hand hygiene. it is necessary to take alcohol-based solutions } \\
\text { regularly. }\end{array}$ & $145(70.4)$ & $61(29.6)$ & $484(69.5)$ & $212(30.5)$ & 0.504 & 0.816 \\
\hline Using gloves replaces hand hygiene requirement. & $26(12.6)$ & $180(87.4)$ & $58(8.3)$ & $638(91.7)$ & 3.461 & 0.063 \\
\hline $\begin{array}{l}\text { Healthcare professionals' hands become a risk factor for } \\
\text { microorganism transfer to patients. }\end{array}$ & 163(79.1) & $43(20.9)$ & $612(87.9)$ & 84(12.1) & 10.186 & 0.001 \\
\hline Hand hygiene trainings adjust hand hygiene malpractices & $194(94.2)$ & $12(5.8)$ & $664(95.4)$ & $32(4.6)$ & 0.516 & 0.472 \\
\hline $\begin{array}{l}\text { Patients still need to re-perform hand hygiene although their hands } \\
\text { are not contaminated. }\end{array}$ & 195(94.7) & $11(5.3)$ & $657(94.4)$ & $39(5.6)$ & 0.021 & 0.885 \\
\hline Hand hygiene is not reduced if gloves do not get dirty. & 154(74.8) & $52(25.2)$ & 534(76.7) & $162(23.3)$ & 0.340 & 0.560 \\
\hline $\begin{array}{l}\text { The improvement of hand hygiene compliance reduces hospital- } \\
\text { based infection speed. }\end{array}$ & 191(92.7) & $15(7.3)$ & 655(94.1) & $41(5.9)$ & 0.528 & 0.467 \\
\hline Good hand hygiene is important for preventing hospital infections. & 194(94.2) & $12(5.8)$ & 684(98.3) & $12(1.7)$ & 10.322 & 0.001 \\
\hline $\begin{array}{l}\text { It is necessary to practice hand hygiene before going into the } \\
\text { patient's room. }\end{array}$ & 198(96.1) & $8(3.9)$ & $683(98.1)$ & $13(1.9)$ & 2.840 & 0.092 \\
\hline It is necessary to practice hand hygiene after taking off the gloves. & 191(92.7) & $15(7.3)$ & $655(94.1)$ & $41(5.9)$ & 0.528 & 0.467 \\
\hline $\begin{array}{l}\text { It is necessary to practice hand hygiene before preparing medication } \\
\text { (treatment). }\end{array}$ & $189(91.7)$ & $17(8.3)$ & $673(96.7)$ & $23(3.3)$ & 9.182 & 0.002 \\
\hline Poor hand hygiene results in cross-contamination. & 189(91.7) & $17(8.3)$ & $673(96.7)$ & $23(3.3)$ & 9.182 & 0.002 \\
\hline $\begin{array}{l}\text { It is necessary to practice hand hygiene before and after each } \\
\text { intervention at the hospital. }\end{array}$ & $194(94.2)$ & $12(5.8)$ & $686(98.6)$ & $10(1.4)$ & 12.865 & 0.000 \\
\hline $\begin{array}{l}\text { We need to clean our hands before touching the patient in order to } \\
\text { prevent the contamination of microorganisms. }\end{array}$ & $197(95.6)$ & $9(4.4)$ & $686(98.6)$ & $10(1.4)$ & 6.627 & 0.010 \\
\hline $\begin{array}{l}\text { It it necessary to practice hand hygiene just after touching the } \\
\text { patient and leaving his / her room. }\end{array}$ & 195(94.7) & $11(5.3)$ & 685(98.4) & 11(1.6) & 9.441 & 0.002 \\
\hline $\begin{array}{l}\text { Prior to intervention and touch. it is necessary to implement aseptic } \\
\text { techniques so as not to transfer microorganisms to other surfaces. }\end{array}$ & 195(94.7) & $11(5.3)$ & $677(97.3)$ & $19(2.7)$ & 3.367 & 0.066 \\
\hline $\begin{array}{l}\text { In order to prevent yourself and others around. it is necessary to } \\
\text { practice hand hygiene after getting exposed to patient's body fluids } \\
\text { such as blood. serum and excretion }\end{array}$ & 202(98.1) & $4(1.9)$ & $684(98.3)$ & $12(1.7)$ & 0.043 & 0.835 \\
\hline $\begin{array}{l}\text { For your safety. it is necessary to practice hand hygiene after } \\
\text { touching the furniture and objects around the patient though there } \\
\text { is no contact with him / her. }\end{array}$ & 195(94.7) & $11(5.3)$ & $682(98)$ & $14(2)$ & 6.534 & 0.011 \\
\hline
\end{tabular}


The majority of participants consisted of female students aged between 18 and 25. The participation of junior and senior students was greater than sophomore students. The majority of respondents had no other family member working as a healthcare professional (Table 1). Zimmerman et al. studies, majority of participants were female and was in the same age group [6]. Regarding participants' responses to questions about hand hygiene, there was a significant difference found between groups. For some statements, sophomore students at second year of their education gave more accurate responses while for others, junior and senior ones being at their third and fourth years of education responded more accurately. For instance, the fourth statement was responded more accurately by sophomores and seniors while the fifth statement had more appropriate responses from junior and senior students. Similarly, the eighth and twelfth statements were responded more accurately by sophomores than both juniors and seniors with a variation on the fourteenth and seventeenth statements, which had more accurate answers from sophomores and seniors to exhibit higher awareness on the issue (Table 2). The results show parallel trend with some previous literature in the sense that those former studies related accurate responses on hand hygiene statements to the lectures given in class with a remark that the highest awareness was detected at the year when students were being exposed to hand hygiene topics during a course [1,6,12-14].

In our research, the students were accepted as a participant to the research after completing their hand hygiene trainings. Focusing on the correlation between hand hygiene and gender, the statements numbered 5, 10,20 and 13 to 17 depict that female students have higher awareness on hand hygiene to reflect statistically significant difference between gender groups, as seen in Table 3. In a previous research, female respondents were found to have more appropriate answers than males for the questions stating two situations "after cough and sneeze" as well as "before and after patient visits". Those results displayed a significant difference between two genders. Another study recorded higher mean scores for female participants on hand hygiene knowledge compared to male participants' scores. The study also emphasized the risk of being male for nonconformity with hand hygiene factors [15]. Similar to other studies in Turkey, these results raise the consideration that females' hand hygiene behaviours are more in harmony with accepted procedures than male behaviours. Skodova et al. also revealed that males were spreading hospital-based infections more than females as being less cautious on hand hygiene than the opposite gender [16].

\section{Conclusion}

The study indicated significant difference of nursing students' hand hygiene awareness regarding gender and class. It is considered that their hand hygiene awareness levels will be increased by incorporating hand hygiene trainings to each year's course schedule regarded by the nursing programme.

Disclosures: There is no conflict of interest for all authors. Acknowledgements: None. Funding: None.

\section{References}

1. Hou C, Scott G, Kraemer M. The Impact of Physician and Nursing Instructors in the Hospital on Awareness of Hand Hygiene inMedical School Students. Oral Abstracts. American Journal of Infection Control. 2016; 44:3-2. https://doi.org/10.1016/j.ajic.2016.04.185

2. Villarreal SEM, S. Khan S, Oduwole M, Sutanto E., Vleck K., Katz M., Greenough W.B. Can educational speech intervention improve visitors' hand hygiene compliance? Journal of Hospital Infection. 2020; 104:414e418. https://doi.org/10.1016/j.jhin.2019.12.002

3. Burke JP. Infection control e a problem for patient safety. N Engl J Med. 2003; https://doi.org/10.1056/NEJMhpr020557

4. Magill SS, O'Leary E, Janelle SJ, Thompson DL, Dumyati G, Nadle J, et al. Changes in prevalence of health care-associated infections in U.S. hospitals. N Engl J Med. 2018; 379(18):1732e44. https://doi.org/10.1056/NEJMoa1801550

5. Pittet, D, Allegranzi, B, Boyce, J. The World Health Organization guidelines on hand hygiene in health care and their consensus recommendations. Infect. Contr. Hosp. Epidemiol. 2009; 30:611-622. https://doi.org/10.1086/600379

6. Zimmerman PAP, Sladdin I, Shaban RZ, Gilberte J, Brown L. Factors influencing hand hygiene practice of nursing students: A descriptive, mixed-methods study. Nurse Education in Practice. 2020; 44:102746. https://doi.org/10.1016/j.nepr.2020.102746

7. Salmon S, Phua MY, Fisher D. One size does not fit all: the effectiveness of messaging for hand hygiene compliance by profession in a tertiary hospital. Journal of Hospital Infection. 2020; 104:435e439. https://doi.org/10.1016/j.jhin.2019.09.008

8. Manresa Y, Abbo L, Sposato K, Pascale de D, Jimenez A. Improving patients' hand hygiene in the acute care setting: Is staff education enough? American Journal of Infection Control. 2019; 000:1-2. https://doi.org/10.1016/j.ajic.2019.12.007

9. WHO. World Health Organization guidelines on hand hygiene in health care. First global patient safety challenge. Clean care is safer care. 2009.

10. Chauhan K, Pandey A, Thakuria B. Hand hygiene: An educational intervention targeting grass root level. Journal of Infection and Public Health. 2019; 12:419-423. https://doi.org/10.1016/j.jiph.2018.12.014

11. Kingstona LM, O'Connell NH, Dunne CP. Survey of attitudes and practices of Irish nursing students towards handhygiene, including handrubbing with alcohol-based hand rub. Nurse Education Today. 2017; 52:57-62. https://doi.org/10.1016/j.nedt.2017.02.015

12. Aktuğ Demir N, Sümer Ş, Demir LS, Ural O. Knowledge Levels of Students, Trainees and Faculty Members About Hand Hygiene at a University Hospital. Klimik Dergisi 2018; 31(2):106-9. https://doi.org/10.5152/kd.2018.26

13. Kaya G., Trabzon Ş., Doğanay S., Güçlü E., Karabay O., Altındiş S., Sağlık Eğitimi Alan Üniversite Öğrencilerine Verilen El Hijyeni Eğitimi Etkinliği. J Biotechnol and Strategic Health Res. 2019; 3(2):219-224. https://doi.org/10.34084/bshr.649305

14. Bahçecioğlu Turan G, Mankan T, Türkben Polat H. Nursing Students' Levels of Knowledge About Hand Hygiene. Gümüşhane University Journal of HealthSciences. GÜSBD. 2017; 6(3):65-70

15. Yüceer S, Demir SG. Yoğun bakım ünitesinde nozokomiyalenfeksiyonların önlenmesi ve hem G̦irelik uygulamaları. Dicle Tip Dergisi. 2009; 36(3):226-233

16. Skodova M, Gimeno-Benítez A, Martínez-Redondo E, Moran-Cortes JF, Jiménez-Romano R, Gimeno-Ortiz A. Hand hygiene technique quality evaluation in nursing and medicine students of two academic courses. Rev. Latino-Am. Enfermagem. 2015; 23(4):708-17. https://doi.org/10.1590/0104-1169.0459.2607 